\title{
Quality parameters of tomatoes submitted to different doses of gamma radiation
} Parâmetros de qualidade de tomates submetidos a diferentes doses de radiação gama

\author{
Ana Carolina Loro' ${ }^{1}$,, Victor Wilson Botteon², Marta Helena Fillet Spoto'* \\ 1 Universidade de São Paulo (USP), Escola Superior de Agricultura "Luiz de Queiroz" (ESALQ), Departamento de Agroindústria, Alimentos e Nutrição, \\ Laboratório de Frutas e Hortaliças, Piracicaba/SP - Brasil \\ 2 Universidade de São Paulo (USP), Centro de Energia Nuclear na Agricultura (CENA), Laboratório de Radiação de Alimentos e Radiobiologia, \\ Piracicaba/SP - Brasil
}

\section{*Corresponding Author}

Marta Helena Fillet Spoto, Universidade de São Paulo (USP), Escola Superior de Agricultura "Luiz de Queiroz" (ESALQ), Departamento de Agroindústria, Alimentos e Nutrição, Laboratório de Frutas e Hortaliças, Avenida Pádua Dias, 11, CEP: 13418-900, Piracicaba/SP - Brasil, e-mail: martaspoto@usp.br

Cite as: Quality parameters of tomatoes submitted to different doses of gamma radiation. Braz. J. Food Technol., v. 21, e2017168, 2018.

Received: Oct. 03, 2017; Accepted: Aug. 06, 2018

\section{Abstract}

Ionizing radiation can be used for different purposes in the food industry. In this study, the effect of irradiation doses (0, 0.5, 1.0 and $1.5 \mathrm{kGy}$ ) on the quality parameters of long life tomatoes (Lycopersicon esculentum Mill.), was evaluated during 4 storage periods $(1,7,14$ and 21 days). The different treatments were evaluated by analysing for colour, $\mathrm{pH}$, total soluble solids (TSS), total titratable acidity (TTA), ratio (TSS/TTA), hardness, total lycopene and ascorbic acid contents, weight loss and maturation stage $\left(\mathrm{O}_{2} / \mathrm{CO}_{2}\right.$ ratio) for all the storage periods. The tomato samples were irradiated in a $\mathrm{Co}^{60}$ irradiator and maintained at $22{ }^{\circ} \mathrm{C} \pm 1{ }^{\circ} \mathrm{C}$. The quality of the tomato fruits was influenced by the gamma radiation basically by making the fruits softer and not degrading the ascorbic acid and lycopene contents at the doses evaluated. The irradiation process used in the doses evaluated was promising with respect to maintaining the quality parameters of long life tomatoes.

Keywords: Physicochemical analysis; Ionizing radiation; Food irradiation; Storage period; Lycopene; Tomato.

\section{Resumo}

A radiação ionizante pode ser utilizada para diferentes fins na indústria alimentícia. Neste estudo, avaliou-se o efeito das doses de irradiação (0, 0,5, 1,0 e 1,5 kGy) nos parâmetros de qualidade nutricional de tomates longa vida (Lycopersicon esculentum Mill.), durante quatro períodos de armazenamento (1, 7, 14 e 21 dias). Os diferentes tratamentos foram avaliados por análises de cor, pH, teor de sólidos solúveis totais (SST), acidez titulável total (ATT), razão (SST/AT), firmeza/textura, teor total de licopeno e ácido ascórbico, perda de peso e fase de maturação (taxa de $\mathrm{O}_{2} / \mathrm{CO}_{2}$ ), em todos os períodos de armazenamento. As amostras de tomate foram irradiadas em irradiador de $\mathrm{Co}^{60}$ e mantidas a $22^{\circ} \mathrm{C} \pm 1^{\circ} \mathrm{C}$. A qualidade dos frutos foi influenciada pelo processo de irradiação, basicamente tornando os frutos mais macios e não degradando os parâmetros de ácido ascórbico e licopeno, nas doses propostas por este estudo. O processo de irradiação, nas doses avaliadas, é promissor na manutenção da qualidade dos tomates longa vida.

Palavras-chave: Análise físico-química; Radiação ionizante; Irradiação de alimentos; Período de armazenamento; Licopeno, Tomate.

\section{Introduction}

Tomato (Lycopersicon esculentum Mill.) is a fruit with great commercial importance, considered one of the most widely cultivated vegetables in the world (CAMARGO; CAMARGO FILHO, 2008) and Brazil is one of the largest producers according to the Food and Agriculture Organization (FAO, 2015).
Brazilian production was 4.29 million tons in 2014 and was estimated at 3.46 million tons for 2015 (IBGE, 2015). The long life tomato cultivars have an extended shelf life because of drastic reductions in the degradation of the pericarp cells, and in the synthesis of ethylene and carotenoids (HERNER; 
SINK, 1973; MUTSCHLER et al., 1992; DELLA VECCHIA; $\mathrm{KOCH}, 2000)$. The irradiation process can improve the quality of the tomatoes and maintain an extended shelf life, besides promoting a reduction in the microbial load and the disinfestation of pests (FARKAS; MOHÁCSI-FARKAS, 2011).

The consumption of tomatoes has been recommended due to their rich nutritional composition, consisting of vitamins, minerals, antioxidants, flavonoids, ascorbic acid and carotenoids such as lycopene, amongst others nutrients and it may also play a preventive role against non-communicable diseases (NCDs) and in reducing the risk of certain cancers (NGUYEN; SHUWARTZ, 1999; GEORGE et al., 2004). One of the major problems affecting the tomato crop is its short shelf life due to oxygen absorption resulting in physicochemical changes, with post-harvest losses of around $21 \%$ in the production chain and $25 \%$ to $40 \%$ in the horticultural sector (RINALDI et al., 2011). Food irradiation technology appears as an alternative to reduce losses and improve post-harvest handling, in addition to contributing to quality maintenance and food safety, with studies aiming to achieve the proposed goals without incurring significant change in the sensory and nutritional parameters (MOHÁCSI-FARKAS et al., 2014).

Previously cited alternative methods known as non-conventional or non-thermal methods, have begun to gain importance in food conservation studies, mainly aiming to reduce losses and obtain safe products with high quality (DIEHL, 2002; SOMMERS; FAN, 2006; THOW; PRIYADARSHI, 2013). Currently, producers and exporters seek technologies such as the food irradiation technique, for sanitary purposes and to increase the shelf life of vegetable products, with a view to expanding foreign markets by meeting international requirements concerning the environment and food security (PEROZZI, 2007; BUSTOS-GRIFFIN et al., 2015).

Ionizing radiation can be used for different purposes in the food industry, highlighting the inactivation of spoilage microorganisms and pathogens, increasing the shelf life of products, pest control and the inhibition of sprouting (FARKAS, 2006; SOMMERS; FAN, 2006; FOLLETT, 2007; DUVENHAGE et al., 2012). Ionizing radiation is that whose energy is greater than that of the energy binding the electrons of atoms, and can be emitted by the radioactive decay of unstable nuclei. It is widely used to improve the physical, chemical and biological properties of materials and commercial products (KIRCHER; BOWMAN, 1964). The main industrial sources are gamma ray ( $\gamma$-ray) and $X$-ray irradiators and electron accelerators. The $\gamma$-ray irradiators are the most commonly used ones for commercial purposes and produce continuous radiation through the natural decay process of radioisotopes such as cobalt-60 $\left(\mathrm{Co}^{60}\right)$ and Cesium-137 ( Cs $^{137}$ ) (HALL, 1994; PINO; GIOVEDI, 2005).

Each food product has its specific nutritional composition and hence a specific procedure should be developed to maintain the organoleptic properties and nutritional quality, ensuring that it can be used without risk to consumer health (IAEA, 1999; DIEHL, 2002). With the regulation of irradiation standards such as the phytosanitary process in agribusiness, the demand for irradiated food products will increase, since the quarantine restrictions can affect the economy of a country (MUMFORD, 2002). Therefore more research must be carried out focused on the nutritional and quality parameters of food products, aiming to determine the limits for radiation doses with respect to quality assurance and food security.

Although several studies have been published on food irradiation, very little information is available on the quality properties of different cultivars of tomatoes after $\gamma$-radiation treatment. This study aimed to verify the effects of different doses of $\gamma$-radiation on the quality parameters of long life tomatoes during 21 days of storage, aiming to determine viable doses that do not compromise the quality of the final product or offer risks to consumer health.

\section{Material and methods}

The study was carried out at the Agroindustry, Food and Nutrition Department of the "Luiz de Queiroz" College of Agriculture (ESALQ/USP), located in Piracicaba-SP, Brazil. The irradiation tests were carried out at the Nuclear and Energy Research Institute (IPEN).

\subsection{Raw material}

Long life tomatoes produced by conventional cultivation were purchased in the green ripening stage at the local market in Piracicaba city, São Paulo state, Brazil. The maturity stage of the tomatoes was visually assessed using the criteria adopted by the USDA (CATALYTIC GENERATORS, 1994). Sample preparation was carried out on the same day samples were taken and radiation processing was carried out 24 hours after preparation. The fruits were immersed in a $0.5 \% \mathrm{NaOCl}$ solution for ten minutes for surface decontamination in the pre-irradiation storage step, and stored for $24 \mathrm{~h}$ at $25{ }^{\circ} \mathrm{C} \pm 1{ }^{\circ} \mathrm{C}$ and $60 \% \pm 10 \% \mathrm{RH}$ in fruit boxes ideal for irradiation (cartons with a capacity for 5 to $6 \mathrm{~kg}$ and dimensions of $365 \mathrm{~cm} \times 275 \mathrm{~cm} \times 135 \mathrm{~cm}$ ).

\subsection{Irradiation process}

The source of gamma radiation was that available at IPEN with an activity of $11.1 \mathrm{PBq}\left(3 \times 10^{5} \mathrm{Ci}\right)$. The dosing of each batch of irradiated fruit was carried out following the Gafchromic ${ }^{\circledR}$ dosimetric system - Gammachrome YR Dosimeter Batch 5, Harwell Laboratory (IAEA, 2004). The dose rate was $3.2 \mathrm{kGy} / \mathrm{h}$ and the distance between the samples and the source of radiation was $20 \mathrm{~cm}$. All samples were transported to the radiation facility and back to the laboratory in cartons and stored in a controlled 
environment room at $23^{\circ} \mathrm{C} \pm 1{ }^{\circ} \mathrm{C}$. The tomatoes were submitted to different irradiation doses: $\mathrm{T} 1=$ control (0 kGy); $\mathrm{T} 2=0.5 \mathrm{kGy} ; \mathrm{T} 3=1.0 \mathrm{kGy}$; and $\mathrm{T} 4=1.5 \mathrm{kGy}$, and analysed for four periods $(1,7,14$ and 21 days).

\subsection{Physicochemical analyses}

Fruit boxes with irradiated tomatoes were stored in a controlled environment room at $22{ }^{\circ} \mathrm{C} \pm 1{ }^{\circ} \mathrm{C}$ and $60 \%$ $\pm 10 \% \mathrm{RH}$. The fruits were chosen at random for analysis amongst those which were suitable for consumption. The physicochemical analyses were carried out for all treatments for the four periods. The parameters analysed were: light transmittance analysis of the pulp (colour), pH, total soluble solids (TSS), total titratable acidity (TTA), ratio (SST/TA), texture, analysis of the carotenoids (total and lycopene), ascorbic acid, weight loss and maturation stage $\left(\mathrm{O}_{2} / \mathrm{CO}_{2}\right.$ ratio $)$.

\subsubsection{Colour}

The colour of the tomatoes was measured using a Minolta colorimeter (Colour Meter 200b) measuring $L^{*}, a^{*}, b^{*}$, Hue and Chroma, where $L^{*}$ represents the lightness, the Hue angle is the tone and Chroma indicates the chromaticity or colour purity. The CIE coordinates $L^{*}, a^{*}, b^{*}$ (Illuminant A) were measured and used to calculate the Chroma value $\left(C^{*}\right)=\left[\left(a^{*} 2+b^{*} 2\right) 1 / 2\right]$, and the hue angle $\left(h^{*}\right)=\tan -1\left(b^{*} / a^{*}\right)($ KONICA MINOLTA, 1998). The fruits were evaluated at nine different points and the means used for the statistical analyses.

\subsection{2 $\mathrm{pH}$}

The $\mathrm{pH}$ was measured using a Tecnal model Tec-3MP $\mathrm{pH}$ meter using samples diluted ten times (10:100), according to Horwitz (2005). The evaluation was carried out in triplicate and the mean values used for the statistical analysis.

\subsubsection{Total Soluble Solids (TSS)}

The total soluble solids were quantified using a portable digital refractometer (Kruss model DR201-95). The results were expressed in ${ }^{\circ}$ Brix according to Horwitz (2005).

\subsubsection{Total Titratable Acidity (TTA)}

The total titratable acidity was determined using a $0.1 \mathrm{M} \mathrm{NaOH}$ solution titrating samples diluted ten times (10:100) according to Horwitz (2005). The results were expressed in $\mathrm{g}$ of citric acid per $100 \mathrm{~g}$ of sample.

\subsubsection{Ratio (TSS/TTA)}

The TSS/TTA ratio was calculated from the ratio of the total soluble solids (TSS) to the total titratable acidity (TTA).

\subsubsection{Hardness}

Instrumental hardness was measured using a Stable Micro Systems texturometer model TA-TX2i with a $2 \mathrm{~mm}$ cylindrical probe which determined the result of the resistance in relation to the force applied by the device in Newtons ( $\mathrm{N}$ ). For the penetration test the probe was moved up and down at $1.0 \mathrm{~mm} \mathrm{~s}^{-1}$ to $10 \mathrm{~mm}$ after the breakdown voltage.

\subsubsection{Lycopene}

Lycopene was extracted and quantified according to the carotenoid methodology of Rodriguez-Amaya (2011) in an environment with poor lighting to avoid photo-oxidation of the pigments. The sample was diluted in cold acetone, vacuum filtered and macerated twice to extract the red colour from the matrix as much as possible. After extraction, petroleum ether was used to partition the carotenoids using a separating funnel, separating the acetone solution from the petroleum ether containing the pigment, which was transferred to a $25 \mathrm{~mL}$ volumetric flask. The absorbance of lycopene was read at $470 \mathrm{~nm}$ in a visible/UV spectrophotometer (Spectrophotomer Model I JK-UVS-752N), and the lycopene content calculated using the Equation 1 below:

Lycopene $(\mu \mathrm{g} / \mathrm{g})=\left(\left(A^{*} y^{*} 10^{6}\right) / A^{1 \%}{ }_{1 \mathrm{~cm}} * 100\right) / \mathrm{m}$

where: $\mathrm{A}=$ wavelength in $\mathrm{nm} ; \mathrm{y}=$ solution volume in $\mathrm{mL}$; $A^{1 \%}{ }_{1 \mathrm{~cm}}=$ carotenoid absorption coefficient; $m$ = sample weight in $\mathrm{g}$.

\subsubsection{Ascorbic acid}

Ascorbic acid was determined using the Tillmans titrimetric method as modified by Benassi and Antunes (1998), which is based on the reduction of 2,6-dichlorophenol-indophenol (DCPIP) by ascorbic acid. $10 \mathrm{~g}$ of tomato were placed in a conical flask containing $50 \mathrm{~mL}$ of $1 \%$ oxalic acid. The contents were filtered into a $25 \mathrm{~mL}$ flask, completed to volume with oxalic acid, and $10 \mathrm{~mL}$ titrated with a $0.2 \%$ solution of 2,6-dichlorophenol-indophenol until the appearance of a pink colour which was stable for 15 seconds. The results were expressed in milligrams

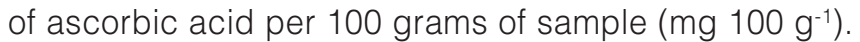

\subsubsection{Weight loss}

The packages with the fruits were weighed on a semi-analytical balance and the results obtained from the difference between the initial weight on the day of the experiment and the weight at the time of sampling, and expressed as the percentage of fresh weight loss. 


\subsubsection{0 $\mathrm{O}_{2} / \mathrm{CO}_{2}$ measurement}

This was determined from the amount of $\mathrm{CO}_{2}$ produced by the tomatoes in hermetically sealed plastic packages. Three tomatoes were placer in each package in triplicate. A Check Mate $\mathrm{O}_{2}$ and $\mathrm{CO}_{2}, \mathrm{PBI}$ Dansensor gas analyser was used for the analysis and the results expressed in $\mathrm{mL} \mathrm{kg}^{-1} \mathrm{~h}^{-1}$.

\subsection{Statistical analysis}

An experimental design with randomized blocks was used with three replicates per treatment, four doses/treatment and four storage times. The data obtained in the physicochemical determinations were submitted to an analysis of variance, and the means compared by the Tukey Y honestly significant difference (HSD) test $(\alpha=0.05)$. The analyses were carried out using the statistical program SAS 9.3 (SAS, 2003).

\section{Results and discussion}

\subsection{Colour}

The tomatoes were initially in the green ripe stage, as reflected in the colour parameters after the irradiation process and storage. Regarding luminosity $\left(L^{*}\right)$, a parameter which goes from 0 to 100 (where 0 is black and 100 is white) and indicates brightness, the results for all radiation doses were higher in the first period (day 1) for all treatments, differing in comparison with the last storage period $(p<0.05)$ (Table 1 ).
Considering the storage period, a decrease in brightness was observed for the last period (day 21), regardless of the treatment, the tomatoes darkening with storage time. The control treatment was brighter at the beginning of storage, differing from the other treatments, while the dose of $1.5 \mathrm{kG}$ showed the lowest values on the first day, only not differing from the radiation dose of 1.0 kGy. The last storage day of the control treatment showed the highest values, the doses of $1.0 \mathrm{kGy}$ and $1.5 \mathrm{kGy}$ not differing from each other (Table 1 ).

Regarding the parameter $\mathrm{a}^{*}$, which measures the tomato colour from green to red, the results for all radiation doses in the first period (day 1) were lower than the other periods analysed, showing that tomatoes, regardless of the dose at the beginning, were redder at the end due to maturation and subsequent senescence. A significant difference $(p<0.05)$ was observed between the first and last period analysed, with the highest value for $a^{*}$ observed in the third period (day 14) and second period for the treatment with a radiation dose of $1.5 \mathrm{kGy}$ and for the control treatment ( $0 \mathrm{kGy}$ ), respectively. For the doses of 0.5 and $1.0 \mathrm{kGy}$ the highest values for $\mathrm{a}^{\star}$ were observed in the fourth period (day 21). On the first day of storage the dose of $1.0 \mathrm{kGy}$ showed higher values, differing from the other treatments, indicating that the tomatoes were redder and probably at a more advanced maturity stage. At the end of the storage period, the dose of 0.5 kGy showed the highest results, because this treatment preserved the colour, differing from the other treatments, and the dose

Table 1. Colour parameters $\left(L^{*}, a^{*}, b^{*}\right.$, Hue and Chroma) of the treated tomatoes $(0,0.5,1.0$ and 1.5 kGy) for the four storage periods ( $1,7,14$ and 21 days).

\begin{tabular}{ccccccc}
$\begin{array}{c}\text { Dose } \\
\text { (kGy) }\end{array}$ & $\begin{array}{c}\text { Storage Period } \\
\text { (days) }\end{array}$ & $\mathbf{L}^{*}$ & $\mathbf{a}^{*}$ & $\mathbf{b}^{*}$ & Hue & Chroma \\
& 1 & $48.22 \pm 0.57 \mathrm{a}$ & $6.73 \pm 1.55 \mathrm{~b}$ & $30.60 \pm 0.86 \mathrm{a}$ & $77.25 \pm 1.42 \mathrm{a}$ & $35.69 \pm 0.68 \mathrm{a}$ \\
0.0 & 7 & $39.80 \pm 0.16 \mathrm{~b}$ & $25.99 \pm 0.40 \mathrm{a}$ & $23.78 \pm 0.64 \mathrm{c}$ & $47.47 \pm 1.28 \mathrm{~b}$ & $34.42 \pm 0.31 \mathrm{a}$ \\
& 14 & $39.64 \pm 0.40 \mathrm{~b}$ & $24.44 \pm 0.14 \mathrm{a}$ & $25.08 \pm 0.22 \mathrm{c}$ & $46.62 \pm 0.44 \mathrm{~b}$ & $34.92 \pm 0.07 \mathrm{a}$ \\
& 21 & $39.59 \pm 0.07 \mathrm{~b}$ & $24.52 \pm 0.38 \mathrm{a}$ & $27.23 \pm 0.26 \mathrm{~b}$ & $47.34 \pm 0.41 \mathrm{~b}$ & $36.73 \pm 0.37 \mathrm{a}$ \\
& 1 & $46.67 \pm 0.36 \mathrm{a}$ & $11.64 \pm 0.20 \mathrm{c}$ & $30.94 \pm 1.48 \mathrm{a}$ & $66.44 \pm 1.05 \mathrm{a}$ & $32.28 \pm 1.23 \mathrm{a}$ \\
0.5 & 7 & $40.52 \pm 0.07 \mathrm{bc}$ & $25.42 \pm 0.09 \mathrm{~b}$ & $25.62 \pm 0.21 \mathrm{~b}$ & $43.86 \pm 0.86 \mathrm{c}$ & $33.33 \pm 0.30 \mathrm{a}$ \\
& 14 & $39.74 \pm 0.36 \mathrm{c}$ & $25.27 \pm 0.30 \mathrm{~b}$ & $25.66 \pm 0.23 \mathrm{~b}$ & $46.26 \pm 0.74 \mathrm{c}$ & $33.53 \pm 0.88 \mathrm{a}$ \\
& 21 & $41.34 \pm 0.57 \mathrm{~b}$ & $28.32 \pm 1.19 \mathrm{a}$ & $25.67 \pm 0.31 \mathrm{~b}$ & $50.09 \pm 0.46 \mathrm{~b}$ & $33.24 \pm 0.42 \mathrm{a}$ \\
& 1 & $45.87 \pm 0.62 \mathrm{a}$ & $17.56 \pm 1.65 \mathrm{~b}$ & $28.70 \pm 0.38 \mathrm{a}$ & $57.54 \pm 2.19 \mathrm{a}$ & $32.43 \pm 2.42 \mathrm{a}$ \\
& 7 & $42.56 \pm 0.23 \mathrm{~b}$ & $22.17 \pm 0.36 \mathrm{a}$ & $26.59 \pm 0.37 \mathrm{~b}$ & $48.84 \pm 0.01 \mathrm{~b}$ & $33.25 \pm 0.41 \mathrm{a}$ \\
& 14 & $40.65 \pm 0.49 \mathrm{bc}$ & $22.56 \pm 0.41 \mathrm{a}$ & $28.44 \pm 0.45 \mathrm{ab}$ & $48.09 \pm 0.71 \mathrm{~b}$ & $33.25 \pm 0.44 \mathrm{a}$ \\
& 21 & $40.43 \pm 0.48 \mathrm{c}$ & $23.75 \pm 0.45 \mathrm{a}$ & $28.27 \pm 0.99 \mathrm{ab}$ & $50.75 \pm 0.55 \mathrm{~b}$ & $32.41 \pm 0.86 \mathrm{a}$ \\
& 1 & $45.31 \pm 0.35 \mathrm{a}$ & $7.85 \pm 0.55 \mathrm{c}$ & $25.87 \pm 1.10 \mathrm{a}$ & $72.16 \pm 0.81 \mathrm{a}$ & $29.33 \pm 1.01 \mathrm{~b}$ \\
& 7 & $41.18 \pm 0.14 \mathrm{~b}$ & $22.69 \pm 0.14 \mathrm{~b}$ & $25.73 \pm 0.23 \mathrm{a}$ & $46.04 \pm 0.20 \mathrm{~b}$ & $35.79 \pm 0,15 \mathrm{a}$ \\
& 14 & $41.04 \pm 0.17 \mathrm{~b}$ & $25.18 \pm 0.51 \mathrm{a}$ & $27.18 \pm 0.07 \mathrm{a}$ & $46.71 \pm 0.57 \mathrm{~b}$ & $37.76 \pm 0.03 \mathrm{a}$ \\
& 21 & $40.93 \pm 0.86 \mathrm{~b}$ & $24.07 \pm 0.35 \mathrm{ab}$ & $26.84 \pm 0.20 \mathrm{a}$ & $47.40 \pm 0.83 \mathrm{~b}$ & $36.70 \pm 0.67 \mathrm{a}$ \\
\hline
\end{tabular}

Different letters in vertical columns for each dose differ significantly $(p<0.05)$. Average of triplicate \pm Standard Deviation. 
of $1.0 \mathrm{kGy}$ presented the lowest value, only differing from the dose of $0.5 \mathrm{kGy}$ (Table 1).

Considering the colour parameter $b^{*}$, the variable that measures the tomato colour from yellow to blue, the values were higher at the beginning, except for the treatment with $1.5 \mathrm{kGy}$, in comparison to the other periods. Tomatoes irradiated with a dose of $0.5 \mathrm{kGy}$ presented higher results initially, but did not differ from the control treatment, while the dose of $1.5 \mathrm{kGy}$ presented the lowest result, differing only from the dose of $0.5 \mathrm{kGy}$. At the end, the dose of $1.0 \mathrm{kGy}$ showed the highest values, only differing from the dose of $0.5 \mathrm{kGy}$ (Table 1).

The Hue angle was calculated from the parameters of $a^{*}$ and $b^{*}$, indicating the shade, and also the value for Chroma (chromaticity) which measures the saturation or colour purity. The Hue angle together with the other colour parameters, help us to informally determine the ripeness stage of fruits and vegetables. In this study, it can be seen the Hue angle showed higher values at the beginning, regardless of the treatment. Higher values for the Hue angle show a greener tomato fruit, and the lower values for the Hue angle indicate increases in the maturation stage.

Regarding the periods, there was a decrease with storage time for all treatments. Significant differences were observed between the treatments at the beginning of storage, the control treatment presenting the highest value, while the dose of $1.0 \mathrm{kGy}$ presented the lowest one, indicating a more advanced stage of maturation (Table 1).

The parameter Chroma showed that the samples were less saturated in the last storage period, with lower values for Chroma values. A non-significant increase in the Chroma value was observed during the storage periods for all treatments, except for the dose of $1.5 \mathrm{kGy}$, which showed a significant increase from the first to the second periods. With respect to the treatments, the control treatment achieved the highest values from the beginning up to the last storage period (Table 1).

The results presented for the colour parameters $\left(L^{*}, a^{*}, b^{*}\right.$, Hue angle and Chroma) indicated that tomatoes were greener initially, becoming reddish, saturated and less bright with time, showing that, depending on the treatment used, the fruit quality was affected to a greater or lesser degree of significance regarding the changes in colour. Helyes et al. (2006) showed that the colour parameters were closely correlated with the degree of maturity of tomato fruits. Castricini et al. (2004) observed greater colour retention when analysing tomatoes of the cultivar 'Deborah Plus' irradiated with doses of 0.25 and $0.5 \mathrm{kGy}$. However, these authors noted that the dose of $1.0 \mathrm{kGy}$ resulted in intensely red coloured tomatoes. However, Fabbri (2009) showed that lower doses were more effective for the fruit colour and that the highest dose showed colour values equal to those of the control treatment (non-irradiated tomatoes).

\section{$3.2 \mathrm{pH}$ value}

The $\mathrm{pH}$ values of the tomatoes were more influenced by the doses of $1.0 \mathrm{kGy}$ and $1.5 \mathrm{kG}$, differing from the other treatments $(p<0.05)$ and showing the highest values at the end of the 21 days (Table 2). The $\mathrm{pH}$ values increased

Table 2. Hardness, Total Soluble Solids (TSS), pH, Titratable Acidity (TA) and Ratio (TSS/TA) of the tomatoes (0, 0.5, 1.0 and $1.5 \mathrm{kGy}$ ) during the four storage periods (1, 7, 14 and 21 days).

\begin{tabular}{ccccccc}
$\begin{array}{c}\text { Dose } \\
\text { (kGy) }\end{array}$ & $\begin{array}{c}\text { Storage Period } \\
\text { (days) }\end{array}$ & Hardness & $\begin{array}{c}\text { Total Soluble } \\
\text { Solids }\end{array}$ & pH & $\begin{array}{c}\text { Titratable } \\
\text { Acidity }\end{array}$ \\
& 1 & $1.68 \pm 0.03 \mathrm{a}$ & $3.40 \pm 0.20 \mathrm{a}$ & $4.36 \pm 0.00 \mathrm{~b}$ & $0.47 \pm 0.02 \mathrm{a}$ & $7.23 \pm 0.61 \mathrm{a}$ \\
0.0 & 7 & $*$ & $2.17 \pm 0.15 \mathrm{~b}$ & $4.40 \pm 0.06 \mathrm{ab}$ & $0.38 \pm 0.02 \mathrm{~b}$ & $5.63 \pm 0.17 \mathrm{~b}$ \\
& 14 & $1.08 \pm 0.16 \mathrm{~b}$ & $2.50 \pm 0.10 \mathrm{~b}$ & $4.48 \pm 0.00 \mathrm{a}$ & $0.37 \pm 0.01 \mathrm{~b}$ & $6.72 \pm 0.23 \mathrm{ab}$ \\
& 21 & $0.72 \pm 0.13 \mathrm{~b}$ & $3.10 \pm 0.10 \mathrm{a}$ & $4.45 \pm 0.04 \mathrm{ab}$ & $0.39 \pm 0.01 \mathrm{~b}$ & $8.06 \pm 0.45 \mathrm{a}$ \\
& 1 & $0.83 \pm 0.08 \mathrm{a}$ & $4.13 \pm 0.15 \mathrm{a}$ & $4.38 \pm 0.05 \mathrm{~b}$ & $0.40 \pm 0.03 \mathrm{a}$ & $9.88 \pm 0.52 \mathrm{a}$ \\
0.5 & 7 & $*$ & $2.10 \pm 0.10 \mathrm{bc}$ & $4.41 \pm 0.01 \mathrm{~b}$ & $0.39 \pm 0.02 \mathrm{ab}$ & $5.42 \pm 0.18 \mathrm{c}$ \\
& 14 & $0.92 \pm 0.08 \mathrm{a}$ & $2.03 \pm 0.15 \mathrm{c}$ & $4.54 \pm 0.00 \mathrm{a}$ & $0.34 \pm 0.01 \mathrm{~b}$ & $5.93 \pm 0.49 \mathrm{c}$ \\
& 21 & $0.52 \pm 0.13 \mathrm{a}$ & $2.50 \pm 0.10 \mathrm{~b}$ & $4.45 \pm 0.02 \mathrm{ab}$ & $0.33 \pm 0.00 \mathrm{~b}$ & $7.61 \pm 0.21 \mathrm{~b}$ \\
& 1 & $1.32 \pm 0.21 \mathrm{a}$ & $2.70 \pm 0.10 \mathrm{a}$ & $4.40 \pm 0.08 \mathrm{~b}$ & $0.39 \pm 0.02 \mathrm{a}$ & $6.95 \pm 0.50 \mathrm{ab}$ \\
& 7 & $*$ & $2.23 \pm 0.06 \mathrm{~b}$ & $4.50 \pm 0.02 \mathrm{~b}$ & $0.36 \pm 0.01 \mathrm{a}$ & $6.16 \pm 0.06 \mathrm{~b}$ \\
& 14 & $1.10 \pm 0.30 \mathrm{a}$ & $2.30 \pm 0.10 \mathrm{ab}$ & $4.62 \pm 0.03 \mathrm{a}$ & $0.32 \pm 0.00 \mathrm{~b}$ & $7.25 \pm 0.41 \mathrm{ab}$ \\
& 21 & $0.75 \pm 0.10 \mathrm{~b}$ & $2.20 \pm 0.20 \mathrm{~b}$ & $4.56 \pm 0.02 \mathrm{ab}$ & $0.29 \pm 0.00 \mathrm{~b}$ & $7.70 \pm 0.80 \mathrm{a}$ \\
& 1 & $0.85 \pm 0.13 \mathrm{ab}$ & $4.17 \pm 0.06 \mathrm{a}$ & $4.29 \pm 0.02 \mathrm{c}$ & $0.41 \pm 0.01 \mathrm{a}$ & $10.33 \pm 0.25 \mathrm{a}$ \\
& 7 & $0.90 \pm .09 \mathrm{a}$ & $4.43 \pm 0.21 \mathrm{a}$ & $4.45 \pm 0.02 \mathrm{~b}$ & $0.41 \pm 0.01 \mathrm{a}$ & $10.83 \pm 0.64 \mathrm{a}$ \\
& 14 & $*$ & $2.47 \pm 0.06 \mathrm{~b}$ & $4.56 \pm 0.01 \mathrm{a}$ & $0.35 \pm 0.01 \mathrm{~b}$ & $6.98 \pm 0.32 \mathrm{~b}$ \\
& 21 & $0.22 \pm 0.03 \mathrm{~b}$ & $2.17 \pm 0.21 \mathrm{~b}$ & $4.58 \pm 0.05 \mathrm{a}$ & $0.27 \pm 0.01 \mathrm{c}$ & $8.13 \pm 1.03 \mathrm{~b}$ \\
\hline
\end{tabular}

Different letters in vertical columns for the same dose differ significantly $(p<0.05)$. Average of triplicate \pm Standard Deviation; *Analysis lost due to equipment problem. 
with storage time for all treatments and decreased slightly between 14 and 21 days, ranging from 4.36 to 4.48 in the control treatment; 4.37 to 4.54 with a radiation dose of $0.5 \mathrm{kGy} ; 4.40$ to 4.61 with $1.0 \mathrm{kGy}$ and 4.29 to 4.57 with $1.5 \mathrm{kGy}$. The control treatment presented less variation (4.36 to 4.44) and become less acid during the last storage period, as also the other treatments. Initially the most acid $\mathrm{pH}$ was observed for the treatment with $1.5 \mathrm{kGy}$ (4.29), becoming less acid at the end of the evaluation period (4.57). The highest mean $\mathrm{pH}$ value was observed with $1.0 \mathrm{kGy}$, differing from the other treatments $(p<0.05)$ (Table 2).

The tomato is considered to be an acidic fruit, and the results found in this study coincide with those of Bleinroth (1995), who stated that the $\mathrm{pH}$ of red ripe tomatoes was around 4.6. Studies with tomatoes showed there was a slight increase in $\mathrm{pH}$ values with the maturing process, due to the fact that their ability to synthesize organic acids became less than the consumption of these substances in the maturation process of the fruits (FERREIRA, 2004). Tavares and Rodriguez-Amaya (1994) found $\mathrm{pH}$ values ranging from 4.4 to 4.6 in fresh Brazilian tomatoes of the cultivar 'Santa Cruz'. The mean $\mathrm{pH}$ values ranged from 4.41 to 4.61 in discarded raw tomato samples and from 4.32 to 4.50 in sterilized samples, in experiments carried out by Nunes and Mercadante (2004). In a study carried out by Gomes et al. (2004), the results showed there were no significant differences during the evaluation periods of 7 and 14 days for tomatoes irradiated with treatments of up to $3.0 \mathrm{kGy}$, but became significant during the later periods evaluated.

\subsection{TSS, TTA and ratio}

The TSS expressed as ${ }^{\circ}$ Brix is the main component responsible for the fruit flavour. The TSS values decreased in the treatments of tomatoes submitted to gamma radiation and maintained their values in the control treatment during the evaluation period, ranging from 3.40 to $3.10^{\circ}$ Brix in the control treatment; 4.13 to $2.50{ }^{\circ} \mathrm{Brix}$ with $0.5 \mathrm{kGy}$; 2.70 to $2.20^{\circ}$ Brix with $1.0 \mathrm{kGy}$ and from 4.16 to $2.16^{\circ}$ Brix with $1.5 \mathrm{kGy}$. Differences $(p<0.05)$ were detected between the treatments, with the highest value (3.30 ${ }^{\circ}$ Brix) observed with the dose of $1.5 \mathrm{kGy}$ (Table 2).

The soluble solids (SS) content depends on the tomato variety, having an important influence on the industrial yield in tomatoes as a raw material for processing (GIORDANO et al., 2000; SHIRAHIGE et al., 2010). Gomes et al. (2004) showed that none of the treatments had any influence on the behaviour of the SS content in tomatoes treated with doses from 0 to $3.0 \mathrm{kGy}$. The ${ }^{\circ}$ Brix values were found to be from 3.8 to 4.0 for tomatoes samples in the study of Nunes and Mercadante (2004), and in the range from 3.8 to 4.6 in fresh tomatoes in the study of Tavares and Rodriguez-Amaya (1994). In turn, Abreu et al. (1997) determined a dose of around 0.6 kGy as a treatment to delay the ripening of tomatoes, detecting mean ${ }^{\circ}$ Brix values of 3.5 and $4.1^{\circ}$ Brix in tomatoes irradiated with doses of 0.3 and $1.0 \mathrm{kGy}$, and $5.0^{\circ}$ Brix for non-irradiated tomatoes.

It was observed that the values for total titratable acidity (TTA) decreased between the initial storage periods and the last period for all treatments, with the highest value being detected in the control treatment (0.38), while the lowest value was observed with the dose of $1.5 \mathrm{kGy}(0.26)$. Significant differences $(p<0.05)$ were detected between the treatments, with the highest mean value observed in the control treatment (0.40) and the lowest value for the dose of 1.0 kGy (0.33) (Table 2).

Due to oxidation, the organic acid content tends to reduce after ripening, with the loss being influenced by the temperature during storage (FENEMA, 1985; SONNENBERG, 1985). Unlike that observed here, the TA values remained constant for tomatoes submitted to different doses of gamma radiation and maintained at room temperature in the study developed by Castricini et al. (2002). Castricini et al. (2004) observed variations in the TA values in tomatoes irradiated at doses of 0.5 and $1.0 \mathrm{kGy}$, while the control tomatoes and tomatoes submitted to a dose of $0.25 \mathrm{kGy}$ maintained their TA levels during the 22 days of evaluation.

The ratio represents that of the total soluble solids and to the total titratable acidity (SST/TTA) and is commonly used as an index for the ripening fruits. The results for ratio only decreased for the treatments with $0.5 \mathrm{kGy}$ and $1.5 \mathrm{kGy}$ during the study period. The ratio ranged from 7.22 to 8.05 in the control treatment; from 9.88 to 7.61 with $0.5 \mathrm{kGy}$; from 6.95 to 7.70 with a dose of $1.0 \mathrm{kGy}$ and 10.33 to 8.13 with $1.5 \mathrm{kGy}$, with the highest mean value observed with $1.5 \mathrm{kGy}$ (9.06), differing from the other treatments $(p<0.05)$. An increase in the ratio was observed for all treatments from 14 to 21 days of storage. The increase observed in the TSS/TTA ratio with a dose of $1.0 \mathrm{kGy}$ and in the control treatment may indicate an improvement in the organoleptic characteristics of the tomatoes (Table 2).

According to Kader et al. (1978), high-quality fruits contain more than $3 \%$ of SS, $0.32 \%$ of TTA and a ratio greater than 10 , indicating a good combination of sugar and acid. No ratio greater than 10 was observed for any treatment at the end of the storage period, only being observed for the first two periods ( 1 and 7 ) for the treatment with $1.5 \mathrm{kGy}$. In the sensory analysis, tomatoes endowed with high values for ratio are correlated with a mild flavour while low values are related to more acid flavours (ZAMBRANO et al., 1996). 


\subsection{Hardness}

According to Chitarra and Chitarra (1990), in fruits hardness involves physical characteristics related to their deformation under the application of a force. The hardness parameter was only maintained during the study period in the treatment with $0.5 \mathrm{kGy}$. A greater loss of hardness was observed with doses of $1.0 \mathrm{kGy}$ and $1.5 \mathrm{kGy}$. The radiation dose of $1.0 \mathrm{kGy}$ differed from the other treatments $(p<0.05)$, with a higher mean value being observed for the control treatment $(1.16 \mathrm{~N})$ (Table 2). The decrease in fruit firmness can be explained by the degradation of starch in the cell wall, the conversion of sugars and the dissolution of pectin substances (CHITARRA; CHITARRA, 1990).

The use of radiation in plant products can lead to losses in texture and softening of the tissues, caused by degradation of the carbohydrates and pectin substances responsible for the hardness of the cell wall components (TUCKER; GRIERSON, 1982; URBAIN, 1996). On the other hand, in the study by Castricini et al. (2004), tomatoes submitted to doses of 0.25 and $0.5 \mathrm{kG}$ y showed maintenance of their degree of hardness up to the $22^{\text {nd }}$ day of storage when kept under refrigeration, corroborating the results found here.

In studies of other irradiated vegetable products, Oliveira et al. (2006) reported a decrease in the texture of non-irradiated and irradiated (300 Gy and 900 Gy) guava fruits, a dose of 600 Gy being more significant than the other doses. Mohácsi-Farkas et al. (2014) also observed statistically significant differences in the texture between non-irradiated and irradiated samples of sliced carrots.
According to Tucker and Grierson (1982) and Wrzodak and Adamicki (2007), the production of the enzyme that triggers the hydrolysis of pectin (polygalacturonase) and is responsible for fruit softening in long life cultivar tomatoes, can be almost completely suppressed by radiation treatment, depending on the dose.

\subsection{Lycopene}

The mean values for lycopene for the irradiation treatments differed significantly from the control treatment $(p<0.05)$. The values for lycopene were maintained for all treatments in the last period of evaluation, presenting a great increase (peak) after 7 and 14 days for the treatments with irradiation and decreasing thereafter, ranging from 39.86 to $40.72 \mu^{-1} g^{-1}$ with a dose of $0.5 \mathrm{kGy}$; from 29.16 to $48.58 \mu \mathrm{g} \mathrm{g} \mathrm{g}^{-1}$ with $1.0 \mathrm{kGy}$; from 18.60 to $75.50 \mathrm{\mu g} \mathrm{g}^{-1}$ with $1.5 \mathrm{kGy}$; and from 13.99 to $23.54 \mu \mathrm{g} \mathrm{g}^{-1}$ in the control treatment (Table 3).

Lycopene is the main carotenoid present in ripened tomato fruits, considered as one of the most efficient antioxidants in the donation of electrons to neutralize oxidant molecules (RAO; AGARWAL, 2000). According to Hart and Scott (1995), ripe tomatoes normally contain about 3 to $5 \mathrm{mg}$ of lycopene per $100 \mathrm{~g}$ of fruit. Tomatoes with an intense red colour have average lycopene levels of around $31 \mu \mathrm{g} / \mathrm{g}$ (RODRIGUEZ-AMAYA, 2011).

The lycopene content varies between different cultivars and conditions and some authors have determined a good correlation between the lycopene content and the colour of the tomatoes, normally increasing as they reach

Table 3. Antioxidant components (Lycopene and Ascorbic Acid - AA) in the tomatoes $(0,0.5,1.0$ and $1.5 \mathrm{kGy})$ during the four storage periods $(1,7,14$ and 21 days).

\begin{tabular}{|c|c|c|c|}
\hline $\begin{array}{l}\text { Dose } \\
\text { (kGy) }\end{array}$ & $\begin{array}{c}\text { Storage Period } \\
\text { (days) }\end{array}$ & $\begin{array}{l}\text { Lycopene } \\
\qquad\left(\mu g^{-1}\right)\end{array}$ & $\begin{array}{c}\text { Ascorbic acid } \\
\left(\mathrm{mg} 100 \mathrm{~g}^{-1}\right)\end{array}$ \\
\hline \multirow{4}{*}{0.0} & 1 & $14.51 \pm 2.67 \mathrm{a}$ & $24.41 \pm 0.04 \mathrm{a}$ \\
\hline & 7 & $23.54 \pm 1.15 \mathrm{a}$ & $22.24 \pm 0.02 b$ \\
\hline & 14 & $14.00 \pm 4.24 a$ & $11.41 \pm 0.01 c$ \\
\hline & 21 & $15.94 \pm 10.30 a$ & $6.30 \pm 0.01 d$ \\
\hline \multirow{4}{*}{0.5} & 1 & $39.86 \pm 2.64 \mathrm{a}$ & $24.41 \pm 0.04 \mathrm{a}$ \\
\hline & 7 & $28.50 \pm 13.39 a$ & $22.11 \pm 0.02 b$ \\
\hline & 14 & $40.73 \pm 22.30 a$ & $11.34 \pm 0.02 c$ \\
\hline & 21 & $17.35 \pm 4.05 a$ & $6.36 \pm 0.01 d$ \\
\hline \multirow{4}{*}{1.0} & 1 & $29.46 \pm 2.28 a$ & $24.26 \pm 0.02 \mathrm{a}$ \\
\hline & 7 & $31.92 \pm 7.78 \mathrm{a}$ & $22.26 \pm 0.01 b$ \\
\hline & 14 & $48.58 \pm 16.32 \mathrm{a}$ & $11.41 \pm 0.01 c$ \\
\hline & 21 & $29.16 \pm 2.43 \mathrm{a}$ & $6.39 \pm 0.01 d$ \\
\hline \multirow{4}{*}{1.5} & 1 & $18.60 \pm 3.37 b$ & $24.12 \pm 0.02 \mathrm{a}$ \\
\hline & 7 & $75.50 \pm 8.50 a$ & $22.19 \pm 0.04 b$ \\
\hline & 14 & $45.69 \pm 11.05 b$ & $11.39 \pm 0.01 c$ \\
\hline & 21 & $21.51 \pm 2.52 b$ & $6.39 \pm 0.01 d$ \\
\hline
\end{tabular}

Different letters in vertical columns for each dose differ significantly $(p<0.05)$. Average of triplicate \pm Standard Deviation. 
the red ripening stage (D'SOUZA et al., 1992; ARIAS et al., 2000; CARVALHO et al., 2005). In Finland, the lycopene concentration in tomatoes was analysed in the summer by Heinonen et al. (1989), showing values ranging from 38 to $66 \mathrm{\mu g} \mathrm{g}^{-1}$, while in the autumn, the values were smaller, ranging from 26 to $31 \mathrm{\mu g} \mathrm{g}^{-1}$. Yang et al. (1987) found a mean lycopene content of $26.1 \mathrm{\mu g} \mathrm{g}^{-1}$ in red ripe tomatoes; Tavares \& Rodriguez-Amaya (1994) observed a mean value of $59.2 \pm 21.8 \mu \mathrm{g} \mathrm{g}^{-1}$ and Nunes and Mercadante (2004) found a range from 28.4 to $93.5 \mathrm{\mu g} \mathrm{g}^{-1}$.

The use of gamma radiation in tomatoes showed an accelerated process of carotenoid accumulation, indicating the possibility of extracting a larger amount of lycopene, due to changes in the chemical structure of the fruit (CASTRICINI et al., 2002). On the other hand, Kumar et al. (2014) showed the lowest mean lycopene contents in tomatoes irradiated with a dose of $1 \mathrm{kGy}$, and the untreated fruits showed a significant increase during the storage period as compared to irradiated fruits, different from that observed in the present study.

The trans-lycopene isomer is present at a concentration of $79 \%$ to $91 \%$ in the tomato and approx. $50 \%$ is in the form of the cis-lycopene isomer (CLINTON et al., 1996). The processing of tomatoes and derivatives may improve the bioavailability of the lycopene, such as heat processing which enables cell wall disruption in the fruits (WILLCOX et al., 2003). Dewanto et al. (2002) showed that heat processing increased the bio-accessibility of lycopene after $2 \mathrm{~min}(3.11 \pm 0.04 \mathrm{mg}$ of trans-lycopene per $\mathrm{g}$ of tomato), $15 \mathrm{~min}$ (5.45 $\pm 0.02 \mathrm{mg}$ of trans-lycopene per $\mathrm{g}$ of tomato), and $30 \mathrm{~min}$ ( $5.32 \pm 0.05 \mathrm{mg}$ of trans-lycopene per $g$ of tomato) of heating at $88^{\circ} \mathrm{C}$.

\subsection{Ascorbic acid}

The treatments differed significantly with respect to the ascorbic acid content of the tomatoes $(p<0.05)$, the control treatment showing the highest

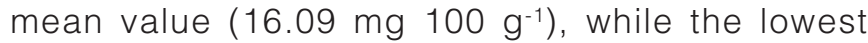
value was observed with $1.5 \mathrm{kGy}\left(16.02 \mathrm{mg} 100 \mathrm{~g}^{-1}\right)$. The behaviour of the ascorbic acid content was similar for all treatments, decreasing in each evaluation period,

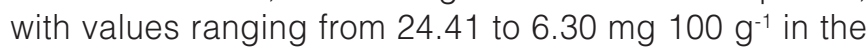

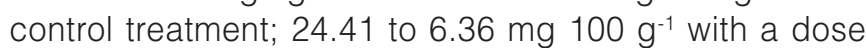
of $0.5 \mathrm{kGy} ; 24.25$ to $6.39 \mathrm{mg} 100 \mathrm{~g}^{-1}$ with $1.0 \mathrm{kGy}$ and

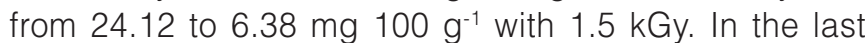

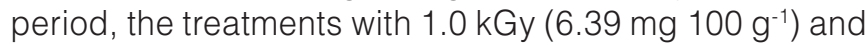

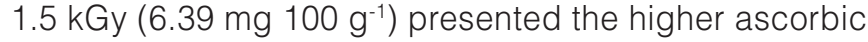
acid contents, while the control treatment presented the lowest concentration (6.30 mg $100 \mathrm{~g}^{-1}$ ) (Table 3).

According to Thayer et al. (1991) ascorbic acid is sensitive to ionizing radiation. During ripening, oxidation of the acids occurs with a reduction in the ascorbic acid content (TUCKER, 1993) and irradiation oxidizes a portion of the ascorbic acid to dehydro-ascorbic acid, also decreasing the amount of ascorbic acid (DIEHL, 1990).
Kilcast (1994) showed a reduction in vitamin levels due to the use of irradiation. Dewanto et al. (2002) observed losses of vitamin $\mathrm{C}$ after 2,15 and 30 min of heating at $88^{\circ} \mathrm{C}$. Corroborating with these results, the effect of gamma irradiation on tomatoes at a dose of $1 \mathrm{kGy}$, promoted a slight decrease in the concentration of ascorbic acid, but no significant decrease in the organoleptic parameters of the fruits (MOHÁCSI-FARKAS et al., 2014).

The ascorbic acid concentration ranged between

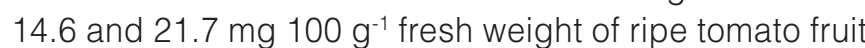
in the study of Abushita et al. (2000), with no differences between cultivars either for fresh consumption or for processed fruit. Tomatoes maintained their levels of ascorbic acid for 20 days of storage when irradiated at a dose of $0.5 \mathrm{kGy}$, but the values showed fluctuations with doses of 1.0 kGy and 2.0 kGy in the study of Gomes et al. (2004). Castricini et al. (2004) observed a higher ascorbic acid content when the fruits were submitted to $0.50 \mathrm{kGy}$ as compared to the treatment with a dose of $1.0 \mathrm{kGy}$.

\subsection{Weight loss}

During fruit storage the transpiration and respiration processes are the main causes of fresh weight loss. Weight loss implies a loss of product quality (BRACKMANN et al., 2007; KLUGE; MINAMI, 1997), and may be caused by the activity of polygalacturonase (PG), the enzyme which increases the permeability of the cell wall, thereby increasing transpiration (FERREIRA, 2004).It is seen therefore important to quantify this parameter to evaluate the quality of the product during storage.

In this study, an increase in weight was observed during the first period, regardless of the treatment, with a significant production of ethylene and increase in respiration, forming reserves and synthesizing compounds (Table 4). There was no significant difference between the treatments $(p<0.005)$ (Table 4). In the second evaluation period, there was a significant increase in weight loss, regardless of the radiation dose, indicating that the tomato decreased its synthesis and increased consumption and respiration. In the third period, there was strong evidence of weight loss; however no difference was detected in comparison with the previous period, regardless of the treatment. The last period was also marked by an increase in weight loss, indicating senescence and a reduced respiration rate since the third storage period (Table 4).

Vieites (1998) evaluated the weight loss of the tomato cultivar 'Debora' in polyethylene containers and found a value of $8.36 \%$ after 21 days of storage under refrigeration. Castricini et al. (2002) found similar levels for fresh weight loss on the $12^{\text {th }}$ day of storage for tomatoes submitted to different doses of $\gamma$-radiation and kept under refrigeration at $12{ }^{\circ} \mathrm{C}$. Bleinroth (1981) noted that the rate of water loss in non-deteriorated vegetables is variable for each plant and should not exceed $10 \%$. 
Table 4. Weight loss of the tomatoes (0, 0.5, 1.0 and $1.5 \mathrm{kGy})$ during the four storage periods $(1,7,14$ and 21 days).

\begin{tabular}{ccc}
$\begin{array}{c}\text { Dose } \\
\text { (kGy) }\end{array}$ & $\begin{array}{c}\text { Storage Period } \\
\text { (days) }\end{array}$ & \% Weight Loss \\
& 1 & $-1.10 \pm 0.17 \mathrm{~b}$ \\
0.0 & 7 & $15.55 \pm 1.21 \mathrm{a}$ \\
& 14 & $14.32 \pm 0.73 \mathrm{a}$ \\
& 21 & $10.90 \pm 1.47 \mathrm{a}$ \\
0.5 & 1 & $-1.33 \pm 0.23 \mathrm{~b}$ \\
& 7 & $14.19 \pm 1.46 \mathrm{a}$ \\
& 14 & $13.97 \pm 1.32 \mathrm{a}$ \\
& 21 & $10.90 \pm 2.29 \mathrm{a}$ \\
1.0 & 1 & $-1.11 \pm 0.27 \mathrm{~b}$ \\
& 14 & $16.10 \pm 2.80 \mathrm{a}$ \\
& 21 & $16.00 \pm 1.39 \mathrm{a}$ \\
& 1 & $11.69 \pm 0.97 \mathrm{a}$ \\
& 7 & $-1.11 \pm 0.39 \mathrm{~b}$ \\
& 14 & $17.43 \pm 1.90 \mathrm{a}$ \\
& 21 & $16.62 \pm 3.70 \mathrm{a}$ \\
& $14.84 \pm 5.15 \mathrm{a}$ \\
\hline
\end{tabular}

Different letters in vertical columns for the same dose differ significantly $(p<0.05)$. Average of triplicate \pm Standard Deviation.

Table 5. $\mathrm{O}_{2}$ and $\mathrm{CO}_{2}$ concentrations of the tomatoes $(0,0.5,1.0$ and $1.5 \mathrm{kGy})$ during the four storage periods $(1,7,14$ and 21 days).

\begin{tabular}{cccc}
$\begin{array}{c}\text { Dose } \\
\text { (kGy) }\end{array}$ & $\begin{array}{c}\text { Storage Period } \\
\text { (days) }\end{array}$ & $\mathbf{O}_{2}$ & $\mathbf{C O}_{2}$ \\
\hline & 1 & $14.74 \pm 1.60 \mathrm{~b}$ & $0.54 \pm 0.05 \mathrm{a}$ \\
0.0 & 7 & $14.58 \pm 0.38 \mathrm{~b}$ & $0.44 \pm 0.05 \mathrm{~b}$ \\
& 14 & $17.53 \pm 0.74 \mathrm{a}$ & $0.30 \pm 0.00 \mathrm{c}$ \\
& 21 & $17.17 \pm 0.45 \mathrm{a}$ & $0.37 \pm 0.06 \mathrm{bc}$ \\
& 1 & $13.64 \pm 0.21 \mathrm{~b}$ & $0.52 \pm 0.04 \mathrm{a}$ \\
0.5 & 7 & $13.28 \pm 0.86 \mathrm{~b}$ & $0.46 \pm 0.05 \mathrm{ab}$ \\
& 14 & $16.32 \pm 0.59 \mathrm{a}$ & $0.30 \pm 0.00 \mathrm{~b}$ \\
& 21 & $16.68 \pm 0.30 \mathrm{a}$ & $0.40 \pm 0.00 \mathrm{~b}$ \\
1.0 & 1 & $13.10 \pm 1.07 \mathrm{~b}$ & $0.50 \pm 0.00 \mathrm{a}$ \\
& 14 & $12.12 \pm 0.87 \mathrm{~b}$ & $0.46 \pm 0.05 \mathrm{ab}$ \\
& 21 & $15.36 \pm 0.24 \mathrm{a}$ & $0.32 \pm 0.04 \mathrm{~b}$ \\
& 1 & $11.38 \pm 0.43 \mathrm{~b}$ & $0.50 \pm 0.00 \mathrm{a}$ \\
1.5 & 7 & $12.04 \pm 0.51 \mathrm{~b}$ & $0.46 \pm 0.05 \mathrm{a}$ \\
& 14 & $15.06 \pm 0.61 \mathrm{a}$ & $0.36 \pm 0.05 \mathrm{~b}$ \\
& 21 & $15.90 \pm 0.00 \mathrm{a}$ & $0.40 \pm 0.00 \mathrm{ab}$ \\
\hline
\end{tabular}

Different letters in vertical columns for the same dose differ significantly $(p<0.05)$. Average of triplicate \pm Standard Deviation.

\section{$3.8 \mathrm{O}_{2} / \mathrm{CO}_{2}$ ratio}

The tomato is a climacteric fruit which still breaths after harvesting, enabling it to be harvested in the ripe green stage, but with full physiological development. In the present study the percentage of $\mathrm{O}_{2}$ and $\mathrm{CO}_{2}$ was evaluated in polyethylene containers. At the beginning of the storage period (from the first to the second periods), independent of the treatment, it was observed that the tomato showed reduced respiration, since the maturation process began to decrease with senescence of the fruits. In the third period (14 days), a more significant reduction in respiration was found for all treatments, indicating the onset of fruit senescence (Table 5).

\section{Conclusion}

- The tomato fruit quality was influenced by the irradiation process basically making the fruits softer (decreasing hardness), but not affecting the other quality parameters, hence not impeding the implementation of irradiation;

- The ascorbic acid and lycopene contents were not degraded by the gamma radiation at the doses applied;

- The irradiation treatments differed from the control treatment in relation to the lycopene content;

- The radiation dose of $1.5 \mathrm{kGy}$ was the treatment showing the highest values for the main bioactive compounds in tomatoes.

\section{Acknowledgements}

The first and second authors are grateful to the Coordenação de Aperfeiçoamento de Pessoal de Nivel Superior (CAPES) for scholarships and to the physicist Mr. Paulo Santos of the Instituto de Pesquisas Energéticas e Nucleares (IPEN) for the irradiation of the tomatoes.

\section{References}

ABREU, T.; SOARES, A.; JESUS, E. Efeitos de diferentes doses de radiação gama absorvidas por tomates pós-colheita. In: MEETING ON NUCLEAR APPLICATION, 4., 1997, Poços de Caldas. Anais... São Paulo: IPEN, 1997. p. 887-892.

ABUSHITA, A. A.; DAOOD, H. G.; BIACS, P. A. Change in carotenoids and antioxidant vitamins in tomato as a function of varietal and technological factors. Journal of Agricultural and Food Chemistry, v. 48, n. 6, p. 2075-2081, 2000. http://dx.doi. org/10.1021/jf990715p. PMid:10888501.

ARIAS, R.; LEE, T. C.; LOGENDRA, L.; JANES, H. Correlation of lycopene measured by HPLC with the $L^{*}, a^{*}, b^{*}$ color readings of a hydroponic tomato and the relationship of maturity with color and lycopene content. Journal of Agricultural and Food Chemistry, v. 48, n. 5, p. 1697-1702, 2000. http://dx.doi. org/10.1021/jf990974e. PMid:10820081.

BENASSI, M. T.; ANTUNES, A. J. A. Comparison of meta-phosphoric and oxalic acids as extractant solutions for the determination 
Quality parameters of tomatoes submitted to different doses of gamma radiation

Loro, A. C. et al.

of vitamin $C$ in selected vegetables. Arquivos de Biologia e Tecnologia, v. 31, n. 4, p. 507-513, 1998.

BLEINROTH, E. W. Matéria prima. In: INSTITUTO DE TECNOLOGIA DE ALIMENTOS - ITAL. Manga: da cultura ao processo e comercialização. São Paulo: Imprensa Oficial do Estado, 1981. cap. 2, p. 243-287. (Frutas Tropicais, 8).

BLEINROTH, E. W. Determinação do ponto de colheita. In: EMPRESA BRASILEIRA DE PESQUISA AGROPECUÁRIA EMBRAPA. Tomate para exportação: procedimentos de colheita e pós-colheita. Brasília: Frupex, 1995. p. 9-20.

BRACKMANN, A.; PINTO, J. A. V.; WEBER, A.; NEUWALD, D. A.; STEFFENS, C. A. Indução da perda de massa fresca e a ocorrência de distúrbios fisiológicos em maçãs 'Royal Gala' durante o armazenamento em atmosfera controlada. Revista Brasileira de Armazenamento, v. 32, n. 2, p. 87-92, 2007.

BUSTOS-GRIFFIN, E.; HALLMAN, G. J.; GRIFFIN, R. L. Phytosanitary irradiation in ports of entry: a practical solution for developing countries. International Journal of Food Science \& Technology, v. 50, n. 1, p. 249-255, 2015. http://dx.doi.org/10.1111/ijfs. 12676.

CAMARGO, F. P.; CAMARGO FILHO, W. P. Produção de tomate de mesa no Brasil, 1990-2006: contribuição da área e da produtividade. Horticultura Brasileira, v. 26, n. 2, p. 10181021, 2008.

CARVALHO, W.; FONSECA, M. E. D. N.; SILVA, H. R. D.; BOITEUX, L. S.; GIORDANO, L. D. B. Estimativa indireta de teores de licopeno em frutos de genótipos de tomateiro via análise colorimétrica. Horticultura Brasileira, v. 232, n. 3, p. 819-825, 2005. http:// dx.doi.org/10.1590/S0102-05362005000300026.

CASTRICINI, A.; MEDEIROS, S. F.; CONEGLIAN, R. C. C.; VITAL, H. C. Uso da radiação gama na conservação pós-colheita do tomate de mesa. Revista Universidade Rural, Série Ciências da Vida, v. 22, n. 2, p. 223-229, 2002

CASTRICINI, A.; MEDEIROS, S.; CONEGLIAN, R. C. C.; VITAL, H. Uso da radiação gama na conservação pós-colheita do tomate de mesa (Lycopersicum esculentum Mill.) em estádio maduro. Revista Universidade Rural, Série Ciências da Vida, v. 24, n. 1, p. 85-91, 2004.

CATALYTIC GENERATORS. Suggested guide for tomato ripening Norfolk: Catalytic Generators, 1994.

CHITARRA, M.I.F.; CHITARRA, A.B. Armazenamento pós-colheita de frutos e hortaliças: fisiologia e manuseio. Lavras: ESAL/ FAEPE, 1990. 293 p.

CLINTON, S. K.; EMENHISER, C.; SCHWARTZ, S. J.; BOSTWICK, D. G.; WILLIAMS, A. W.; MOORE, B. J.; ERDMAN JUNIOR, J. W. Cis-trans lycopene isomers, carotenoids and retinol in the human prostate. Cancer Epidemiology, v. 5, n. 10, p. 823-833, 1996. PMid:8896894
D'SOUZA, M. C.; SINGHA, S.; MORRIS, I. Lycopene concentration of tomato fruit can be estimated from chromaticity values. HortScience, v. 27, n. 5, p. 465-466, 1992.

DELLA VECCHIA, P. T.; KOCH, P. S. Tomates longa vida: o que são, como foram desenvolvidos? Horticultura Brasileira, v. 18, n. 1, p. 3-4, 2000. http://dx.doi.org/10.1590/S0102-05362000000100001.

DEWANTO, V.; WU, X.; ADOM, K. K.; LIU, R. H. Thermal processing enhances the nutritional value of tomatoes by increasing total antioxidant activity. Journal of Agricultural and Food Chemistry, v. 50, n. 10, p. 3010-3014, 2002. http://dx.doi.org/10.1021/ jf0115589. PMid:11982434.

DIEHL, J. F. Safety of irradiated foods. New York: Marcel Dekker, 1990.

DIEHL, J. F. Food irradiation - past, present and future. Radiation Physics and Chemistry, v. 63, n. 3-6, p. 211-215, 2002. http:// dx.doi.org/10.1016/S0969-806X(01)00622-3.

DUVENHAGE, A. J.; JOOSTE, M.; JOHNSON, S. A. Irradiation as a postharvest quarantine treatment for a new pluot cultivar. Scientia Horticulturae, v. 147, p. 64-70, 2012. http://dx.doi. org/10.1016/j.scienta.2012.09.007.

FABBRI, A. D. T. Estudo da radiação ionizante em tomates in natura (Lycopersicum esculentum Mill.) e no teor de licopeno do molho. 2009. 85 f. Tese (Dissertação de Mestrado em Tecnologia Nuclear)-Universidade de São Paulo, São Paulo, 2009. http://dx.doi.org/10.11606/D.85.2009.tde-22092011-141423.

FARKAS, J. Irradiation for better foods. Trends in Food Science \& Technology, v. 17, n. 4, p. 148-152, 2006. http://dx.doi. org/10.1016/j.tifs.2005.12.003.

FARKAS, J.; MOHÁCSI-FARKAS, C. History and future of food irradiation. Trends in Food Science \& Technology, v. 22, n. 2, p. 121-126, 2011. http://dx.doi.org/10.1016/j.tifs.2010.04.002.

FENEMA, Q. R. Food chemistry. New York: Marcel Dekker, 1985. FERREIRA, S. M. R. Características de qualidade de tomate de mesa (Lycopersicon esculentum Mill.) cultivado nos sistemas convencional e orgânico comercializado na região metropolitana de Curitiba. 249 f. 2004. Tese (Doutorado em Tecnologia de Alimentos)-Universidade Federal do Paraná, Curitiba, 2004

FOLLETT, P. A. Postharvest phytosanitary radiation treatments: less-than-Probit 9, generic dose, and high dose applications. In: VREYSEN, M. J. B.; ROBINSON, A. S.; HENDRICHS, J. (Ed.). Area-wide control of insect pests. The Netherlands: Springer, 2007. p. 425-433. http://dx.doi.org/10.1007/978-1-4020-6059-5_40.

FOOD AND AGRICULTURE ORGANIZATION OF THE UNITED NATIONS - FAO. Produtividade mundial. Rome: FAO, 2015. Available at: <http://faostat.fao.org/site/339/default.aspx>. Accessed on: 8 June 2016.

GEORGE, B.; KAUR, C.; KHURDIYA, D. S.; KAPOOR, H. C. Antioxidants in tomato (Lycopersium esculentum) as a function 
Quality parameters of tomatoes submitted to different doses of gamma radiation

Loro, A. C. et al.

of genotype. Food Chemistry, v. 84, n. 1, p. 45-51, 2004. http:// dx.doi.org/10.1016/S0308-8146(03)00165-1.

GIORDANO, L. B.; SILVA, J. B. C.; BARBOSA, V. Escolha de cultivares e plantio. In: SILVA J. B. C.; GIORDANO, L.B. Tomate para processamento industrial. Brasília: Embrapa Informação Tecnológica, 2000. p. 36-59.

GOMES, V. M.; CONEGLIAN, R. C. C.; CASTRICINI, A.; MEDEIROS, S. F.; VITAL, H. D. C. Utilização de atmosfera modificada e radiação gama na manutenção da qualidade de tomate de mesa (Lycopersicum esculentum Mill.) em pós-colheita: avaliação química. Revista Universidade Rural, Série Ciências da Vida, v. 24, n. 1, p. 99-105, 2004.

HALL, E. J. Radiobiology for the radiologist. 4th ed. Philadelphia: JB Lippincott., 1994.

HART, D. J.; SCOTT, K. J. Development and evaluation of an HPLC method for the analysis of carotenoids in foods, and the measurement of the carotenoid content of vegetables and fruits commonly consumed in the UK. Food Chemistry, v. 54, n. 1, p. 101-111, 1995. http://dx.doi.org/10.1016/0308-8146(95)92669-B.

HEINONEN, M. I.; OLLILAINEN, V.; LINKOLA, E. K.; VARO, P. T.; KOIVISTOINEN, P. E. Carotenoids in finnish foods: vegetables, fruits, and berries. Journal of Agricultural and Food Chemistry, v. 37, n. 3, p. 655-659, 1989. http://dx.doi.org/10.1021/jf00087a017.

HELYES, L.; PÉK, Z.; LUGASI, A. Tomato fruit quality and content depend on stage of maturity. HortScience, v. 41, n. 6, p. 14001401, 2006

HERNER, R. C.; SINK, K. C. Ethylene production and respiratory behavior of the Rin tomato mutant. Plant Physiology, v. 52, n. 1, p. 38-42, 1973. http://dx.doi.org/10.1104/pp.52.1.38. PMid: 16658495

HORWITZ, W. (Ed.). Official methods of analysis of the Association of Official Analytical Chemists. 18th ed. Gaithersburg: AOAC, 2005.

INSTITUTO BRASILEIRO DE GEOGRAFIA E ESTATÍSTICA IBGE. Levantamento sistemático da produção agrícola. Rio de Janeiro: IBGE, 2015. Available at: <http://www.ibge.gov.br/ home/estatistica/indicadores/agropecuaria/lspa>. Accessed on: 8 June 2016.

INTERNATIONAL ATOMIC ENERGY AGENCY - IAEA. Facts about food irradiation: consultive group on food irradiation. Vienna: IAEA, 1999.

INTERNATIONAL ATOMIC ENERGY AGENCY - IAEA. Dosimetry system for SIT: standard operating procedure for gafchromic film. Vienna: IAEA, 2004

KADER, A. A.; MORRIS, L. L.; STEVENS, M. A.; ALBRIGHTHOLTON, M. Composition and flavour quality of fresh market tomatoes as influenced by some postharvest handling procedures. Journal of the American Society for Horticultural Science, v. 113, p. 742-745, 1978.
KILCAST, D. Effect of irradiation on vitamins. Food Chemistry, v. 49, n. 2, p. 157-164, 1994. http://dx.doi.org/10.1016/03088146(94)90152-X.

KIRCHER, J. F.; BOWMAN, R. E. Effects of radiation on materials and components. New York: Reinhold, 1964.

KLUGE, R. A.; MINAMI, K. Efeito de ésteres de sacarose no armazenamento de tomates Santa Clara. Scientia Agrícola, v. 54, n. 1-2, p. 39-44, 1997. http://dx.doi.org/10.1590/S010390161997000100006.

KONICA MINOLTA. Comunicação precisa da cor: controle de qualidade da percepção à instrumentação. Seoul: Konica Minolta, 1998.

KUMAR, M.; AHUJA, S.; DAHUJA, A.; KUMAR, R.; SINGH, B. Gamma radiation protects fruit quality in tomato by inhibiting the production of reactive oxygen species (ROS) and ethylene. Journal of Radioanalytical and Nuclear Chemistry, v. 301, n. 3 , p. 871-880, 2014. http://dx.doi.org/10.1007/s10967-014-3234-7.

MOHÁCSI-FARKAS, C.; NYIR -FEKETE, B.; DAOOD, H.; DALMADI, I.; KISKÓ, G. Improving microbiological safety and maintaining sensory and nutritional quality of pre-cut tomato and carrot by gamma irradiation. Radiation Physics and Chemistry, v. 99, p. 79-85, 2014. http://dx.doi.org/10.1016/j.radphyschem.2014.02.019.

MUMFORD, J. D. Economic issues related to quarantine in international trade. European Review of Agriculture Economics, v. 29, n. 3, p. 329-348, 2002. http://dx.doi.org/10.1093/eurrag/29.3.329.

MUTSCHLER, M. A.; WOLFE, D. W.; COBB, E. D.; YOURSTONE, K. S. Tomato fruit quality and shelf life in hybrids heterozygous for the alc ripening mutant. HortScience, v. 27, n. 4, p. 352-355, 1992.

NGUYEN, M. L.; SHUWARTZ, S. J. Lycopene: chemical and biological properties. Food Technology, v. 53, n. 2, p. 38-45, 1999.

NUNES, I. L.; MERCADANTE, A. Z. Obtenção de cristais de licopeno a partir de descarte de tomate. Food Science and Technology, v. 24, n. 3, p. 440-447, 2004. http://dx.doi.org/10.1590/ S0101-20612004000300024.

OLIVEIRA, A. C. G. D.; ZANÃO, C. F. P.; ANICETO, A. P. P.; SPOTO, M. H. F.; CANNIATTI-BRAZACA, S. G.; WALDER, J. M. M. Conservação pós-colheita de goiaba branca kumagai por irradiação gama: aspectos físicos, químicos e sensoriais. Boletim do Centro de Pesquisa e Processamento de Alimentos, v. 24, n. 2, p. 375-396, 2006. http://dx.doi.org/10.5380/cep.v24i2.7496.

PEROZZI, M. Irradiação: tecnologia boa para aumentar exportações de frutas. Inovação Uniemp, v. 3, n. 5, p. 42-44, 2007

PINO, E. S.; GIOVEDI, C. Radiação ionizante e suas aplicações na indústria. Revista Unilus Ensino e Pesquisa, v. 2, n. 2, p. 47-51, 2005.

RAO, A. V.; AGARWAL, S. Role of antioxidant lycopene in cancer and heart disease. Journal of the American College of Nutrition, v. 19, n. 5, p. 563-569, 2000. http://dx.doi.org/10.1080/073157 24.2000.10718953. PMid:11022869. 
Quality parameters of tomatoes submitted to different doses of gamma radiation

Loro, A. C. et al.

RINALDI, M. M.; SANDRI, D.; OLIVEIRA, B. N.; SALES, R. N.; AMARAL, R. D. A. Avaliação da vida útil e de embalagens para tomate de mesa em diferentes condições de armazenamento. Boletim do Centro de Pesquisa e Processamento de Alimentos, v. 29, n. 2, p. 305-316, 2011. http://dx.doi.org/10.5380/cep. v29i2.25510.

RODRIGUEZ-AMAYA, D. B. A guide to carotenoid analysis in foods. Washington: ILSI Press, 2011.

SHIRAHIGE, F. H.; MELO, A.; PURQUERIO, L. F. V.; CARVALHO, C. R. L.; MELO, P. Produtividade e qualidade de tomates Santa Cruz e Italiano em função do raleio de frutos. Horticultura Brasileira, v. 28, n. 3, p. 292-298, 2010. http://dx.doi.org/10.1590/ S0102-05362010000300009.

STATISTICAL ANALYSIS SYSTEM - SAS. SAS version 9.1. Cary: SAS Institute Inc., 2003.

SOMMERS, C. H.; FAN, X. Advances in gamma ray, electron beam, and X-ray technologies for food irradiation. In: CLELAND, M. R. Food irradiation, research and technology. Ames: Blackwell Publishing, 2006. 11 p. http://dx.doi.org/10.1002/9780470277638.

SONNENBERG, P. E. Olericultura especial: cultura de alface, alho, cebola, cenoura, batata e tomate. 5. ed. Goiania: Universidade Federal de Goiais, 1985. p. 123-179.

TAVARES, C. A.; RODRIGUEZ-AMAYA, D. B. Carotenoid composition of Brazilian tomatoes and tomato products. LebensmittelWissenschaft + Technologie, v. 27, n. 3, p. 219-224, 1994. http://dx.doi.org/10.1006/fstl.1994.1045.

THAYER, D. W.; FOX JUNIOR, J. B.; LAKRITZ, L. Effects of ionizing radiation on vitamins. In: THORNE, S. (Ed.). Food irradiation. London: Elsevier Applied Science Publishers, 1991. p. 285-325.

THOW, A. M.; PRIYADARSHI, S. Aid for trade: an opportunity to increase fruit and vegetable supply. Bulletin of the World
Health Organization, v. 91, n. 1, p. 57-63, 2013. http://dx.doi. org/10.2471/BLT.12.106955. PMid:23397351.

TUCKER, G. A. Introduction. In: SEYMOUR, G. B.; TAYLOR, J. E.; TUCKER, G. A. (Ed.). Biochemistry of fruit ripening. London: Champman \& Hall, 1993. p. 2-51.

TUCKER, G.; GRIERSON, D. Synthesis of polygalacturonase during tomato fruit ripening. Planta, v. 155, n. 1, p. 64-67, 1982. http://dx.doi.org/10.1007/BF00402933. PMid:24271628.

URBAIN, W. M. Food irradiation. New York: Academic Press, 1996. $351 \mathrm{p}$.

VIEITES, R. L. Conservação pós-colheita do tomate através do uso da radiação gama, cera e saco de polietileno, armazenados em condições de refrigeração e ambiente. 1998. 131 f. Tese (Livre-Docência em Ciências Agronômicas)--Universidade Estadual Paulista, Botucatu, 1998.

WILLCOX, J. K.; CATIGNANI, G. L.; LAZARUS, S. Tomatoes and cardiovascular health. Critical Reviews in Food Science and Nutrition, v. 43, n. 1, p. 1-18, 2003. http://dx.doi. org/10.1080/10408690390826437. PMid:12587984.

WRZODAK, A.; ADAMICKI, F. Effect of temperature and controlled atmosphere on the storage of fruit from long-life tomatoes. Vegetable Crops Research Bulletin, v. 67, n. 1, p. 177-186, 2007. http://dx.doi.org/10.2478/v10032-007-0041-5.

YANG, C. C.; BRENNAN, P.; CHINNAN, M. S.; SHEWFELT, R. $L$. Characterization of tomato ripening process as influenced by individual seal-packaging and temperature. Journal of Food Quality, v. 10, n. 1, p. 21-23, 1987. http://dx.doi. org/10.1111/j.1745-4557.1987.tb00286.x.

ZAMBRANO, J.; MOYEJA, J.; PACHECO, L. Efecto del estado de madurez en la composición y calidad de frutos de tomate. Agronomía Tropical, v. 46, p. 61-72, 1996. 